\title{
Why is design-build commonly used in the public sector? An illustration from Hong Kong
}

Edmond W.M. Lam, PhD Candidate, Albert P.C. Chan, Professor, and Daniel W.M. Chan, Assistant Professor

(Department of Building and Real Estate, Hong Kong Polytechnic)

\section{ABSTRACT}

The Design and Build (D\&B) procurement method is one of the systems advocated to overcome inadequacies with the traditional procurement method. In recent years, this innovative procurement method has been put to practice in Hong Kong where a vast amount of infrastructure works is taking place. This paper aims to illustrate the applicability of design-build in the Hong Kong setting. As most D\&B projects are undertaken by the public sector of Hong Kong, the main features of a public sector project and reasons for its wider use on D\&B are fully examined in the paper. To further explore the benefits of $D \& B$ in actual practice, structured interviews have been conducted with clients, contractors and consultants running D\&B projects in Hong Kong. Summary of major problems of running D\&B projects from the previous study by the authors is also outlined. With the increasing use of D\&B in the public sector of Hong Kong and worldwide, more research can be undertaken on the quantitative comparison of the traditional mode of procurement and how to carry out a D\&B project successfully so as to develop a knowledge base for the D\&B procurement method.

Keywords-design-build, construction, characteristics, public sector, Hong Kong

\section{INTRODUCTION}

The adoption of the traditional design-bid-build method in the building industry has become a common practice (Rowlinson and Walker, 1995). However, the increasing complexity of buildings, the need to reduce design and construction periods and the increasing burden of contract administration urge the clients and designers to find better and more efficient ways to deliver projects (Chan et al., 1999). As a result, clients have been seeking more efficient procurement routes in order to have better time, quality and risk performance in recent decades.

Design-build (D\&B) contracts become increasingly popular as the construction industry seeks less adversarial and more integrated project procurement strategies (Palaneeswaran and Kumaraswamy, 2001). They appear to be a panacea to many of the problems faced by the practitioners. Research and surveys reported in the construction press indicate considerable growth of the design and build approach (Ndekugri and Church, 1996). It has been used around the globe extensively and its popularity has grown substantially over the last 10 years (Ernsen and Schexnayder, 2000).
In the last decade, D\&B has also been used extensively in Hong Kong to help deal with the problems associated with the traditional system (Chan, 2000). It is mostly implemented by the public sector which has shown an increasing acceptance of design-build in recent years (Rizzo, 1998). It is a common goal for most governments to introduce more innovative and efficient methods in delivering public building projects. However, D\&B is not without problems and practitioners in the industry may increasingly show concerns on the benefits of the D\&B method in actual practice.

This paper analyses the applicability of the D\&B adoption in the public sector of Hong Kong. It aims to identify the key characteristics of the D\&B method and account for its wider adoption in the public sector. It also provides an empirical study on the benefits of the D\&B method in actual practice and summarises the potential problems of running $D \& B$ projects from a previous study. The paper is divided into five parts. It first presents an overview of the design-build development in the Hong Kong setting. More detailed analysis in terms of the characteristics of public sector projects and the reasons for the popular use of D\&B in the Public Sector of Hong Kong will then be provided.

Structured interviews have also been conducted with practitioners in the industry to study the benefits of the D\&B method in actual practice. Potential problems of running $D \& B$ projects are then summarised from a previous survey. The significance of this study will also be highlighted at the end of the paper.

\section{DEVELOPMENT OF DESIGN-BUILD}

\section{PROCUREMENT SYSTEM IN HONG KONG}

$D \& B$ has been a popular alternative procurement method (Palaneeswaran and Kumaraswamy, 2000). It has experienced extraordinary growth in recent years and there have been increasing reports of adopting the design and build method to procure complex projects in the UK and the US (Deakin, 1999).

Among the Asian-countries, Hong Kong has adopted various types of procurement systems, including the separated, integrated and management-oriented methods (Masterman, 2002). While management contracting has not been used to any great degree, the design and build approach which uses contractors' expertise to a much greater extent is being increasingly used in Hong Kong (Hatush and Skitmore, 1997). 


\section{Trend of the design-build adoption in Hong Kong}

In the past, D\&B was only carried out on an ad hoc basis in Hong Kong, with insignificant difference between the public and private sector (Lam, 1990). The development and use of non-traditional forms of contracting is becoming more common and the D\&B procurement method has become accepted by the construction industry of Hong Kong in the last few years (Tam, 1997). The total contract value in the last 20 years is about $3 \%$ of the total expenditure, which is about HK\$50 billion for D\&B main contracts compared with the total expenditure exceeding HK\$1,600 billion (Pearson and Skues, 1999).

D\&B has been used in civil engineering works since 1980 (Rowlinson and Walker, 1995). Because of the implementation of the Ten Airport Core Programme Projects, Hong Kong gradually applies D\&B to its infrastructure development projects, such as the construction of Tsing Ma Bridge, Kap Shui Mun Bridge and Ma Wan Viaducts. In the building sector, the first D\&B project was adopted by the Architectural Services Department (ASD) in 1989 to procure the Vietnam Refugee Centre (Chan and Yung, 2000). The success of the project encouraged the ASD to consider applying D\&B in other government projects and thus the use of $D \& B$ is gradually promoted (Deakin, 1999).

Indeed, most D\&B projects in Hong Kong are used in the public sector. Over $40 \%$ of the D\&B projects undertaken by construction firms in Hong Kong are public works while private user-clients tend to use D\&B for specific projects only (Chan and Yung, 2000).

\section{Use of the design-build procurement in the public sector of Hong Kong}

The government is the single largest client of the construction industry and is responsible for all buildings needed for public services (Rowlinson and Walker, 1995). While the traditional procurement arrangement is still adopted in the majority of projects, the use of D\&B is increasing, particularly in the public sector because the government begins to award major contracts on this basis, with the publication of the General Conditions of Contract for Design and Build Contracts in May 1992. Such contract document was later revised in 1999 with administrative procedures. It is used by the government in hospital, infrastructure, minor works and housing projects. This reflects the situation that the D\&B procurement system is gaining its popularity in the public sector (Lam and Chan, 1995).

\section{The Hospital Authority (HA)}

The Hospital Authority of Hong Kong was established in December 1990. To cater for the increasing needs on health care facilities, the enhanced form of D\&B was adopted to achieve the rapid delivery of projects, including North District Hospital, Tseung Kwan O Hospital and later the redevelopment of the Grantham Hospital (Deakin, 1999; Wilkins, 1999).

\section{The Hong Kong Housing Authority (HKHA)}

The Hong Kong Housing Authority (HA) was established in early 1954. The Housing Department, the executive arm of The HA, introduced the Private Sector Participation Scheme (PSPS) in 1977 as a supplement to the Home Ownership Scheme (HOS). In fact, The PSPS has all the characteristics of a D\&B project by using the resources of the private sector in terms of design, construction, supervision of production and project management (Ho et al., 1996).

\section{The Environment, Transport and Works Bureau}

The Environment, Transport and Works Bureau of the Hong Kong Special Administrative Region (HKSAR) is responsible for the management of the public sector construction work other than housing such as government buildings, roads, reclamation and bridges. It consists of seven departments related to public works projects, namely:

- The Architectural Services Department (ASD)

- The Drainage Services Department (DSD)

- The Electrical and Mechanical Services Department (EMSD)

- The Highways Department (HyD)

- The Territory Development Department (TDD)

- The Water Supplies Department (WSD)

- The Civil Engineering Department (CED)

All except the Electrical and Mechanical Services Department and the Territory Development Department have projects procured by $D \& B$ and the numbers of some major $D \& B$ projects in the government organisations of Hong Kong from 1992 to 2001 are shown in Table 1.

\begin{tabular}{|l|c|c|c|c|c|c|c|}
\hline $\begin{array}{l}\text { Government } \\
\text { organisations }\end{array}$ & HA & HKHA & ASD & DSD & HyD & WSD & CED \\
\hline $\begin{array}{l}\text { Number of } \\
\text { D\&B Projects }\end{array}$ & 2 & 20 & 21 & 3 & 3 & 1 & 5 \\
\hline
\end{tabular}

Table 1: The numbers of major $D \& B$ projects in the government organisations of Hong Kong (Chan et al., 2003/04; Hong Kong Housing Authority, 2002; Environment, Transport and Works Bureau, 2002)

Of the various government departments, the ASD accounted for about one-third of the projects in the public sector and its trend in D\&B adoption can well illustrate the increasing significance of D\&B projects in the public sector (Chan and Yung, 2000). 


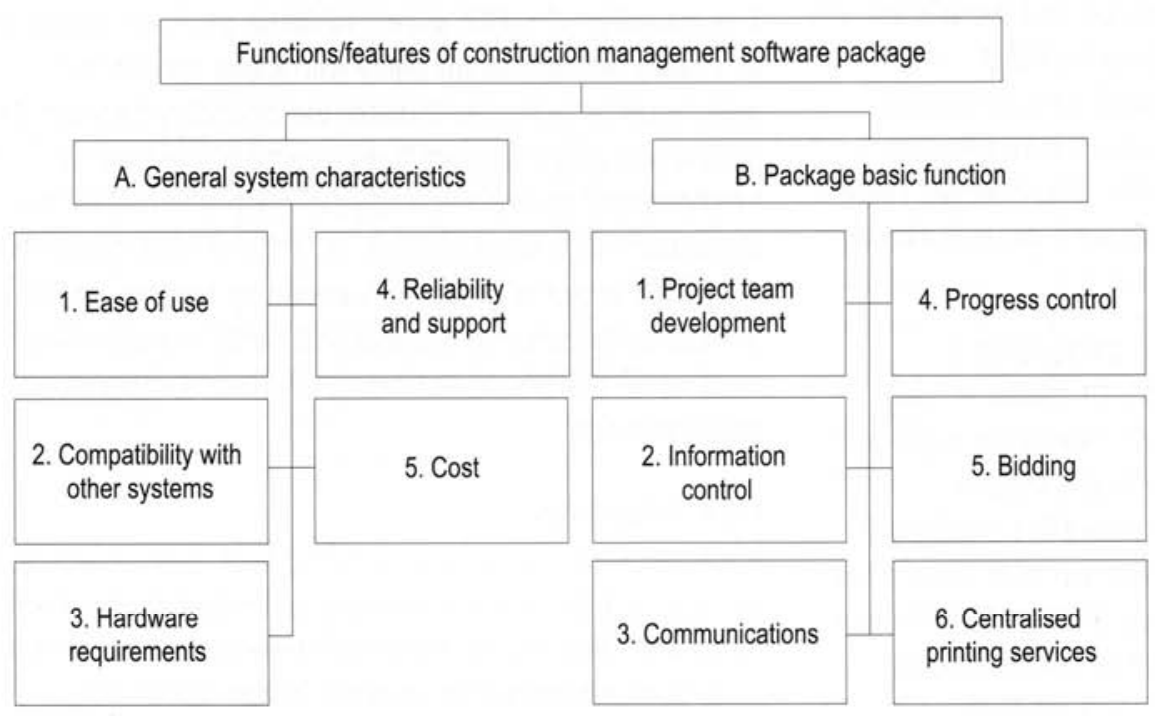

Figure 1: The trend of the use of D\&B projects in the ASD over the past eight years (Source: Chan et al., 2001)

\begin{tabular}{|l|r|r|r|r|r|r|r|r|}
\hline Year & 1992 & 1993 & 1994 & 1995 & 1996 & 1997 & 1998 & 1999 \\
\hline$\%$ & 2.36 & 6.53 & 3.44 & 22.21 & 18.5 & 23.89 & 5.89 & 46.14 \\
\hline
\end{tabular}

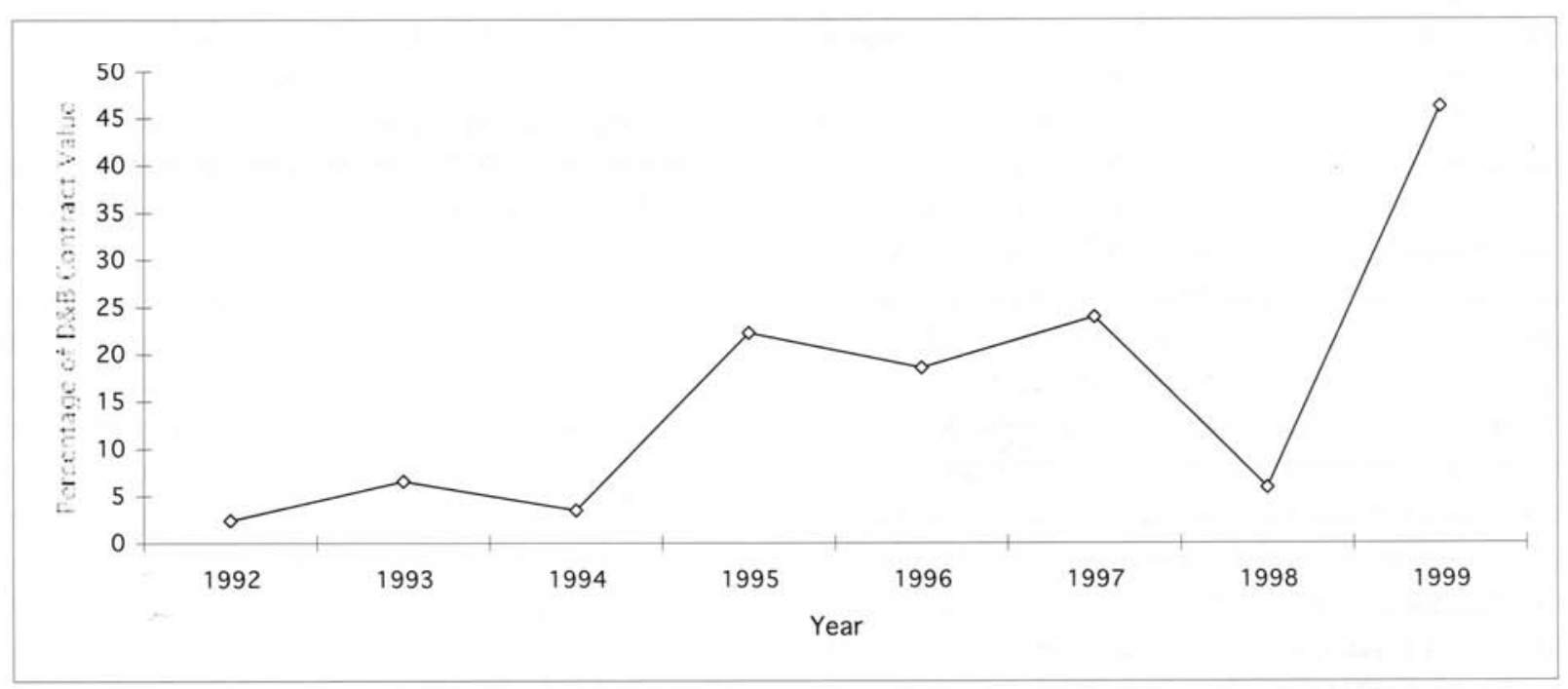

Figure 2: The proportion in total contract value of D\&B projects in the ASD over the past eight years (Source: Chan et al., 2001) 
Figure 1 shows the trend of the use of D\&B projects in the ASD over the past 8 years. It is revealed that there is an increasing number of projects adopting the $D \& B$ procurement method in the ASD, from $0.91 \%$ in 1992 to $9.91 \%$ in 1999 , with a sudden increase of $D \& B$ projects tendered out in 1999. The proportion in total contract value of D\&B projects in the ASD over the past 8 years is shown as Figure 2.

The contract value of $D \& B$ projects increased from HK\$68.58 million in 1992 to HK\$6025.41 million in 1999 , with an increase of nearly a hundred times in the eight-year period. The total $D \& B$ contract value over the total construction contract value also increased in the period, from $2.36 \%$ in 1992 to $46.14 \%$ in 1999 , which is almost half of the total construction contract value in The ASD. There is indeed a large investment in the D\&B projects in Hong Kong, indicating a significant influence of the $D \& B$ procurement method in the Public Sector of Hong Kong.

Hong Kong has developed an effective design and build procurement system. Other procurement forms like the professional construction management (PCM) may not be widely used in Hong Kong because of the unfamiliarity of the project participants with such a method. PCM is the basic form of construction management where an agent, construction manager, performs design functions from the start till the end of construction (Haltenhoff, 1986). Contractors in Hong Kong may find it difficult to coordinate various professionals under PCM which demands a multi-disciplinary organisation. Moreover, PCM requires a well-organised system for registration, licensing and certification of a construction manager, which is absent in the public sector of Hong Kong. The Hong Kong construction industry is characterised by the multi-layered sub-contracting structure (CIRC, 2001). Under PCM, the work is administratively controlled by a separate entity which performs little or no direct construction work-the construction manager. Therefore, coordination can be a problem which adds a heavy burden to the client. Like the construction manager, the specialist contractors enter into direct contracts with the client, who needs to bear the risks on time and price. Indeed, several court decisions from overseas hold the government responsible for delays and associated costs, indicating an increased risk of government liability when using the CM system (Scott and Showalter, 1986). While the traditional procurement arrangement is still adopted in the majority of projects, the use of D\&B is increasing since the government begins to award major contracts on this basis (Lam and Chan, 1995). In fact, there are several characteristics of public sector projects that enhance the adoption of the D\&B procurement method.

\section{CHARACTERISTICS OF PUBLIC SECTOR PROJECTS}

The meaning of 'public sector' is rather abstract. Huque et al. (1998) define it as an entity with ideas related to governmental activities. Indeed, the boundary between the private and public sectors has become blurred as the functions and operations always overlap that makes the distinction much more difficult. In fact, the management of the public sector is greatly influenced by existing social, political and economic realities and better management requires a clearer understanding of public sector project characteristics.

\section{Clear objectives}

Public projects are usually launched with clear objectives to convince the concerned approval authorities for funding purposes. They usually have tight time constraints and a lump sum determined in advance (Chan, 2000). The requirements of time, cost and quality are heavily stressed as the principal concern areas where cost certainty is an important selection criterion to be addressed (Palaneeswaran and Kumaraswamy, 2000).

\section{Well-established project procedures}

Public projects are being tendered out under rigid rules and regulations through open and fair competition with high levels of bureaucracies. Normally, the tender with the lowest bid is accepted (CIRC, 2001).

\section{Rigid rules and regulations}

Unlike private sector organisations, government organisations usually procure a project under many governing rules and regulations (Palaneeswaran and Kumaraswamy, 2000). They are also bound by legislation. Therefore, they have been criticised as inert to innovation and rapid change. Even those public bodies that genuinely wish to change, standing orders and procedures sometimes render it impossible. Clients in public funding projects are also not encouraged to issue variations after the contract is signed because it will reduce the degree of certainty on project cost. Flexibility to change is not so important in the public sector since the commercial factor and the profitoriented objective do not normally exist (Palaneeswaran and Kumaraswamy, 2000).

\section{Open and fair competition}

All bidders are given the same information of public sector projects to prepare their bids and they are always treated equally without discrimination. All necessary information provided in the tender documents and all procurement procedures and practices are clear and transparent to facilitate better understanding among contractors. In fact, selection is made on both the less tangible aspects of social public interest, public support and political backing, and the more tangible elements of technical performance, cost and 
schedule (Riggs et al., 1992). Moreover, prequalification screening is essential to cater for the need for open competition through public bidding for public sector projects, especially for design-build projects where there is a scoring system to select the design and build contractor

(Palaneeswaran and Kumaraswamy, 2000). This involves a screening procedure based on a set of prequalification criteria and requires contractors to plan the organisations of the design and construction teams, design strategy, quality assurance strategy, safety and cost management to ensure that the contract can be carried out satisfactorily if it is awarded to them (Hatush and Skitmore, 1997).

\section{High levels of bureaucracies}

Public sector projects are implemented by several government departments with specific interests and skills. Such departments have different roles to play and have various degrees of authority towards the approval of public sector projects. There is also a considerable number of client changes during the construction phase (Smith and Wilkins, 1996). As a result, it is generally observed in the divergent practices of the public clients that there is a lack of communications among such clients (Palaneeswaran and Kumaraswamy, 2000). Moreover, common 'knowledge sharing platforms' in public organisations are rare so some useful experiences cannot be disseminated properly. Public sector projects are required to undergo several approval procedures which are lengthy and have eventually led to public works being generally considered as centrally controlled, bureaucratic and inefficient (Wilkins, 1999). Indeed, public clients need to incorporate most of the modern management tools and technologies to cope with the growing demands of the construction industry to remain competitive and make optimal use of scarce resources.

\section{Acceptance of the lowest bid}

Normally, public clients are constrained to select the lowest bidder for contracting, except in extraordinary cases (Palaneeswaran and Kumaraswamy, 2000). They are bound to follow a 'minimum needs doctrine' in public sector procurement to demonstrate that value for money has been obtained (Wilkins, 1999). In fact, the acceptance of the lowest bid can best illustrate the need for complete public accountability and the concept of 'value for money' (Smith and Wilkins, 1996).

\section{Emphasis on the public}

In most cases, public acceptance is required prior to implementation of public sector projects. Public clients in a public agency can only buy what they actually need, not what they want. The need for a building is no exception as the project may be subject to public hearings and some engineering teams may need to interact with the public (Culp and Smith, 2001). Indeed, the main concerns of public clients are public accountability and certainty of cost.
Traditionally, the idea of accountability has been very much attached to the use of public resources, especially public funds (Leong, 1991; Mo and Ng, 1997). Government institutions and their related organisations should constantly be aware that they are accountable to the tax-paying public for their effective and efficient use. In fact, public accountability has been considered an important aspect in project delivery in the public sector, and extended and complex government approval procedures have been established from the pressures of accountability (Chan et al., 1999).

Price certainty is usually established for government projects because of public accountability (Chan, 2000). The public sector has a duty to ensure that the community gets maximum value from the available resources - best value for money (Finance Bureau, 2000). Moreover, clients of public funding projects are not encouraged to take risk and they have to know about the operations of the project clearly (Mo and $\mathrm{Ng}, 1997)$.

The twin objectives of 'value for money' and 'public accountability' have, in the past, been seen to be most easily achieved by acceptance of the lowest tender. Recent literature suggests other principles of delivering a public sector project effectively, including 'fitness for purpose', reputation, ethics and environmental concerns (Kumaraswamy and Walker, 1999).

In recent years, public sector owners are rapidly identifying new construction procurement methods for the delivery of public sector projects (Molenaar and Songer, 1998). $D \& B$ has emerged as an alternative to the more traditional options of open competitive tendering for procuring public projects. It is a popular mode of procuring construction work and the 1990s have seen an explosion of D\&B in the public sector (Akintoye, 1994). In fact, the characteristics of D\&B projects can account for its increasing use in the public sector.

MATCHING D\&B FEATURES WITH PUBLIC SECTOR PROJECT CHARACTERISTICS

Public sector clients have high regard for accountability, value for money and certainty of completion. They experimented with $D \& B$ with varying degrees of success due to a number of benefits that D\&B can offer.

\section{Single point of communication}

One benefit that $D \& B$ offers is the single-point responsibility that has drastically increased productivity at both pre- and post-contractual stages (Franks, 1998). In the public sector, it is recognised that there is usually a lack of communications of end-user requirements in the brief development and design stages-a 'multi-headed client problem' (Smith and Wilkins, 1996). As a result, there is diffusion of decision-making and difficulty in allocating responsibility. D\&B allows the concerned parties to meet 
and discuss detailed requirements through direct communication with the contractor who is responsible for the design, construction, planning, organisation and control of the project. Such integrated nature of teams improves communication between designers and builders and encourages a prompt response. It is especially advantageous in the public sector where high levels of bureaucracies occur and hence it is better to introduce onepoint communication.

\section{Certainty on time and cost}

$D \& B$ enables public sector clients to have firmer control of time. It offers a faster approach than the traditional procurement method as the fast track concept of overlapping the design and construction is possible (Hong Kong Construction Association, 1990). As construction can be commenced before the completion of design, the project duration can be shortened. Such characteristics of D\&B projects can be better achieved in the public sector as public sector clients can better follow the application procedures. On some occasions, government projects can have exemptions from different statutory requirements and there is no need to queue for long processing time of documentation (Deakin, 1999; Huque et al., 1998). As a result, public sector clients can be more certain of when the project is finished which has important cost implications.

In D\&B projects, there are certainties in controlling the design of contractors since the client's requirements are well defined and stable at the project inception stage. Therefore, the early cost certainty is possible through D\&B (Franks, 1998). This criterion is important, particularly in public sector projects as it is considered essential to have a fixed price determined well in advance. D\&B is chosen because of the definite completion date and the guaranteed cost which are the prime concerns for public sector projects (Chan and Yung, 2000).

\section{Use of contractor's expertise}

D\&B enables combining both the contractor and design consultants' expertise where the special expertise of the contractor can be utilised (Hong Kong Construction Association, 1990). The contractor can have more control over the design and introduce components which are more economical to construct and so productivity can be enhanced. Moreover, the closer involvement of the design consultants in the building process can lead to designs having a greater appreciation of construction methodsbuildability (Works Bureau, 1999). It also provides opportunities for innovation and excellence to come up with the design of the best value for money (Palaneeswamy and Kumaraswamy, 2000).

\section{Pre-qualification exercises}

Prequalification is a pre-tender process used to investigate and assess the capabilities of contractors to carry out a contract satisfactorily if it is awarded to them (Hatush and Skitmore, 1997). This involves a screening procedure based on a set of prequalification criteria, instead of just using the low bid criterion which is not necessarily able to justify the 'value for money' concept (Palaneeswamy and Kumaraswamy, 2000). Such a screening process is essential, especially in public sector projects to ensure that they are tendered out to technically competent contractors to increase the chance of project success. It also enables public sector clients to have maximum economy of cost in every project so that the one with the best value for money can be selected. Fairness and competitiveness can be ensured which is a special demand of public accountability for public funded projects (Tam, 1997).

\section{Use of private sector resources}

Many public sector clients nowadays have sought to privatise social services to minimise financial and managerial effort (La Grange and Prestorius, 1996). As each project has to satisfy the specific needs of a particular sector of society, the public sector gradually relies on the construction companies to manage the whole project on a design and construct basis (Walker, 1995).

In fact, the use of the D\&B procurement method in the public sector enables public sector clients to enjoy some benefits of privatisation, including the risk transfer to the private sector, the increase in operating efficiency and the streamlining of the size of the public sector (Lam, 1990). As many construction projects are planned in the public sector, the lack of resources in the government will cause delays in projects. Therefore, the use of private sector resources can provide social benefits and D\&B can reduce the government's resources for design work, reduce claims and help lower risks (Songer and Molenaar, 1996).

\section{Government initiation}

The public sector in every country has certain commitments to the public towards project completion so that projects can serve their functions as stated. Such commitments have indeed put great pressure on the public sector to complete projects as soon as possible. Therefore, the public sector has become more innovative in procurement methods to deliver the projects more effectively.

To be more innovative in the context of contract documents, the public sector of Hong Kong produced a D\&B contract in the 1990s. Moreover, in 1999, administrative procedures were established to complement the General Conditions of Contract for D\&B projects to maintain the consistency in the common understanding of D\&B. Such a move not only shows the intention of the public sector to use $D \& B$ in future projects, but also creates an image that $D \& B$ is one major 
procurement system. In fact, the enactment of the Standard Forms of Design and Build Contract can combat ambiguities and uncertainties which are particularly important in construction projects where disputes commonly arise (Deakin, 1999). A firm government commitment and the promotion by the government to take the lead in using D\&B can indeed provide a strong justification for the adoption of such a new alternative procurement method.

\section{EMPIRICAL SURVEY ON THE USE OF THE D\&B METHOD \\ Benefits of D\&B}

Various literature reported on the benefits of the $D \& B$ procurement method but it is questionable whether the application of D\&B can better meet the requirements of construction projects. An empirical study has been conducted with ten D\&B participants in Hong Kong on the benefits of adopting the D\&B method in their residential quarters projects by means of structured interviews during December 2001 and June 2002. The respondents are notably the client, the contractor and the consultant and are represented by the prefixes Clt-, Ctr- and Cot- respectively. Details of the respondents are shown in Table 2.

\begin{tabular}{|l|l|l|}
\hline Reference no. & Group & Project \\
\hline Ctr1 & Contractor & LOR Quarters \\
\hline Clt2 & Client & LOR Quarters \\
\hline Cot3 & Consultant & LOR Quarters \\
\hline Cot4 & Consultant & LOR Quarters \\
\hline Ctr5 & Contractor & FL Quarters \\
\hline Clt6 & Client & LOR Quarters \\
\hline Clt7 & Client & LCL Quarters \\
\hline Clt8 & Client & HNR Quarters \\
\hline Ctr9 & Contractor & HNR Quarters \\
\hline Ctr10 & Contractor & WKR Quarters \\
\hline
\end{tabular}

Table 2: Details of interviewees

One client interviewee believed that there were on the whole few disputes that arose from the quarters projects because D\&B can be used to take the advantage of the contractor in terms of better buildability with possible cost savings in materials at a lower price and to the required quality (Clt2). It can allow the completion of a project at high certainty of time and cost and make good use of the contractor's expertise (Clt7, Clt8). D\&B is advantageous in its fast track construction since the design time is squeezed to provide a faster project delivery (Clt6). It also allows flexibility of project and the contractors of the quarters projects were claimed to be rather innovative and keen on providing alternatives regarding the choice of materials (Clt7).
The contractor interviewees believed that $D \& B$ enables the client to rely heavily on the fast track experience of the contractor who is believed to have good time management to control the whole project (Ctr1, Ctr10). One contractor interviewee even claimed that D\&B can save time by at least seven times in the design stage when compared with the traditional method and there is usually cost reduction when the project is finished (Ctr5). As the design is not fixed, more innovative ideas can be obtained from the various tenderers who can contribute more input and construction knowledge to the design of the project to increase the efficiency and effectiveness of construction process (Ctr1, Ctr10). Therefore, even if the tender price of the project is not the lowest, the proposal will still be selected because of the better design from the contractor (Ctr5). D\&B can also avoid disputes as the contractor provides a single point of responsibility to further enhance the coordination of the project (Ctr1, Ctr9).

D\&B allows an early determination of time and cost (Cot4). It is preferred because of the enormous dispute and claim issues in the use of traditional contracts and the government may find ways to a smoother project delivery method to settle the final accounts (Cot3). In fact, there were fewer variation orders in $D \& B$ because of the $D \& B$ nature where few design discrepancies were encountered (Cot3, Cot4). A better relationship among the project participants can also be maintained under $D \& B$, which puts forward earlier the potential claims before disputes arise (Cot3).

It is clear that $D \& B$ provides single point of communication to reduce disputes and enhance the coordination of the project. It also allows high certainty of time and cost and makes good use of the contractor's expertise for better buildability of the project. The selection mechanisms also enable the best 'value-for-money' option to be awarded. However, D\&B, like other procurement systems, may not be perfect in all circumstances.

\section{Can D\&B be problem-free?}

The use of $D \& B$ is on the increase worldwide, especially in the public sector where public accountability is of utmost importance in delivering public sector projects. D\&B provides benefits to project participants but indeed, no one single procurement system is free from problems and D\&B is no exception. Lam et al (2003) provided a comprehensive desk study on the potential problems of running D\&B projects from the viewpoints of client, contractor and consultant (Fig. 3). So long as appropriate management strategies are administered and harmonious relationships are established among project team members, D\&B can still be one effective procurement tool for public sector projects. 
Problems associated with the client

Preconstruction stage

Caused by the Group:

- Lengthy evaluation of tenders

- Unclear client's requirements

Faced by the Group

- Little interaction with the tenderers

- Little choice on market

Construction stage

Caused by the Group

- Frequent and late changes

- Delay of design approval

Faced by the Group

- Restricted control over the project

\section{Problems associated with the contractor}

Faced by the Group:

- Lack of management expertise

- Tendering burden

- Misinterpretation of client's requirements

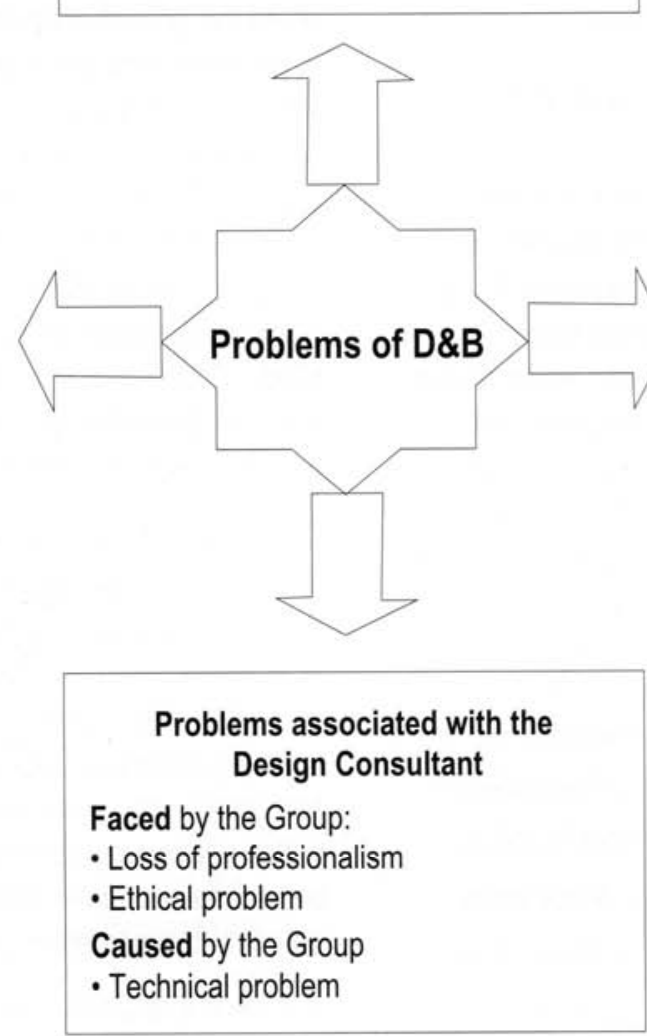

Other considerations

- Unclear about responsibilities

- Conflicts in interpretation of client's requirements

- Resistance to change

- Frequent changes from end-users

- Late approval from related statutory organisations

- Lack of trust and respect

- Divergent attitudes

towards D\&B

- Concerns on 'corner-cutting'

- Lack of confidence

Figure 3: Potential problems of running D\&B projects (Lam et al., 2003)

\section{SIGNIFICANCE OF THE STUDY}

The traditional procurement system is flawed with a number of problems (Latham, 1994). However, Rwelamila and Hall (1994) argued that the problems are not necessarily the fault of the traditional design-bid-build system, but may be conceived as the failure to manage the 'human aspect' effectively and attempts have been made to search for a procurement system with better coordination of various project participants. As a result, the industry strongly advocates the use of innovative procurement systems of which $D \& B$ is increasingly popular. The Construction Industry Review Committee in Hong Kong considers D\&B to be one method for construction process re-engineering to achieve better integration in project delivery processes (CIRC, 2001). It recommends D\&B be adopted more widely in both the public and the private sectors. This paper is expected to be a positive contribution to encouraging both the initiation and effectiveness of the more integrated procurement arrangements.
Many governments have sought to privatise social services. In Hong Kong, The PSPS is chosen to maximise revenue to the public sector (La Grange and Pretorius, 1996). A study of the reasons for the wider adoption of $D \& B$ in the public sector represents an important shift from the traditional lowbid procurement procedures to a more integrated 'value-formoney' project delivery method. It also enables further understanding of the characteristics of this innovative procurement system in meeting the established government objectives of public sector project delivery. Still, D\&B is not without problems and the management level should consider properly different procurement systems in their decision-making.

The public sector is the largest client in Hong Kong (Walker, 1995). It is the key to an effective construction industry. If more projects in the public sector are procured by D\&B, contractors may be encouraged to further develop their $D \& B$ knowledge in order to stay competitive to bid for future projects. Once they are familiarised with D\&B, the level of 
adoption will be increased and even extended to the private sector. As a consequence, the use of D\&B should be significantly promoted across a broad spectrum of the construction industry.

\section{CONCLUSIONS}

This paper attempts to give an overview of the D\&B development in the public sector of Hong Kong. The characteristics of public sector projects are presented, including clear objectives, well-established project procedures in terms of rigid rules and regulations, open \& fair competition, high levels of bureaucracies and acceptance of the lowest bid, and emphasis on the public. Moreover, reasons for the wider use of D\&B in the public sector can be attributed to its characteristics, notably single point of communication, certainty on time \& cost, use of contractor's expertise, pre-qualification exercises, use of private sector resources and government initiation. While $D \& B$ may not be a perfect procurement method, key findings from the empirical study with D\&B practitioners in Hong Kong show that the benefits of $D \& B$ can also be realised in actual practice. More research can be focused on the quantitative comparison of the traditional mode of procurement. With the increasing adoption of the $D \& B$ procurement method in the public sector, further research can be conducted on how to carry out a D\&B project successfully, particularly in the Hong Kong context so as to develop a knowledge base for further promotion on the use of $D \& B$ in Hong Kong and other parts of the world.

\section{ACKNOWLEDGEMENTS}

The authors gratefully acknowledge the respondents for providing valuable information in interview surveys and The Hong Kong Polytechnic University for providing funding to support this research effort.

\section{REFERENCES}

Akintoye, A. (1994). Design and build: a survey of construction contractors' views. Construction Management and Economics, 12(2), 155-163.

Chan, A. P. C. (2000). Evaluation of enhanced design and build system: A case study of a hospital project. Construction Management and Economics, 18 (8), 863-871.

Chan, A. P. C., Yu, A. T. W. and Tam, C. M. (1999). Enhanced design build-An Innovative system to procure a hospital project. In: Ogunlana S. O. (Ed.) Profitable

Partnering in Construction Procurement, CIB W92 and CIB TG 23 Joint Symposium, E\&FN Spon, Longdon, 405-415.

Chan, A. P. C. and Yung, E. H. K. (2000). Research monograph: Procurement selection model for Hong Kong, Department of Building and Real Estate, The Hong Kong Polytechnic University.
Chan, A. P. C., Scott, D. and Lam, E. W. M. (2001). Study of design \& build projects in Hong Kong. Proceedings of The Third International Conference on Construction Project Management, 29-30 March 2001, Singapore, 366-376.

Construction Industry Review Committee (CIRC) (2001). Construct for excellence-Report of the Construction Industry Review Committee 2001, HKSAR.

Culp, G. and Smith, A. (2001). Understanding psychological type to improve project team performance. Journal of Management in Engineering, ASCE, 17(1), 24-33.

Deakin, P. (1999). Client's local experience on design and build projects. Seminar Proceedings on Design and Build Procurement System, January 1999, Hong Kong, 11-16.

Environmental, Transport and Works Bureau (2002). Unpublished Statistics from Note for Public Works Subcommittee of Finance Committee, Hong Kong.

Ernsen, J. J. and Schexnayder, C. (2000). One company's experience with design/build: labour cost risk and profit potential. Journal of Construction Engineering and Management, ASCE, 126(1), 10-14.

Finance Bureau (2000). Enhanced productivity programme (1999-2000), HKSAR.

Franks, J. (1998). Building procurement systems: A client's guide, 3rd edition, England: Chartered Institute of Building.

Haltenhoff, C. E. (1986). The forms and variations of the CM system, Construction Management: a state-of-the-art update, October 27, 1986, Boston, Massachusetts, USA, $1-15$.

Hatush, S. and Skitmore, M. (1997). Assessment and evaluation of contractor data against client goals using PERT approach. Construction Management and Economics, 15(1), 327-340.

Ho, D. C. W., Chau, K. W. and Leung, H. F. (1996).

Are contractors prepared to take on design and build contracts. Proceedings of CIB W92_-Procurement Systems North meets South: Developing Ideas, South Africa, 14-17 January 1996, 213-224.

Hong Kong Construction Association (1990). Design and build sub-group report to the joint discussion group on the standard form of conditions of contract. Hong Kong Construction Association, Occasional Paper.

Hong Kong Housing Authority (2002). Unpublished statistics from Housing Authority Contracts under Private Sector Participation Scheme, Hong Kong.

Huque, A. S., Lee, G. O. M. and Cheung, A. B. L. (1998). The civil service in Hong Kong continuity and change. Hong Kong University Press, Hong Kong. 
Kumaraswamy, M. M. and Walker, D. H. T. Multiple performance criteria for evaluating construction contractors. Procurement systems: a guide to best practice in construction, New York: E\&FN Spon, 228-251.

La Grange, A. and Pretorius, F. (1996). Privatization of public housing in Hong Kong: An assessment of the private sector participation scheme. Proceedings of CIB W92Procurement Systems North meets South: Developing Ideas, 14-17 January 1996, South Africa, 261-274.

Lam, E. W. M., Chan, A. P. C. and Chan, D. W. M. (2003). Potential Problems of Running Design-Build Projects in Construction. HKIE Transactions. (In press).

Lam, P. T. I. (1990). Report on a critical comparison of the construction procurement and contracting systems in Japan, Singapore, Malaysia and Hong Kong. Department of Building and Surveying, Hong Kong Polytechnic: Hong Kong.

Lam, P. T. I. and Chan, A. P. C. (1995). An empirical study of design and build and other procurement approaches in AsiaPacific countries. Design and Build Projects-International Experiences, International Congress on Construction, 5-6 October 1995, Singapore, 213-222.

Latham, M. (1994). Constructing the Team-A Report on the UK Construction Industry, HMSO, UK.

Leong, C. (1991). Accountability and project management: a convergence of objectives. International Journal of Project Management, 9(4), 241-249.

Masterman, J. W. E. (2002). Introduction to building procurement systems. 2nd ed., London; New York.

Mo, J. K. W. and Ng, L. Y. (1997). Design and build procurement method in Hong Kong - An overview. CIB W92 Symposium Procurement - a key to innovation, University de Montreal, 20-23 May 1997, 453-463.

Molenaar, K. R. and Songer, A. D. (1998). Model for public sector design-build project selection. Journal of Construction Engineering and Management, 124(6), 467-479.

Ndekugri, I. and Church, R. (1996). Construction procurement by the design and build approach: A survey of problems. Proceedings of CIB W92 Procurement Systems North meets South: Developing Ideas, South Africa, 14-17 January 1996, 452-462.

Palaneeswaran, E. and Kumaraswamy, M. M. (2000). Benchmarking contractor selection practices in public-sector construction - a proposed model. Engineering, Construction and Architectural Management 2000, 7(3), 285-299.

Palaneeswaran, E. and Kumaraswamy, M. M. (2001). Reinforcing design-build contractor selection: A Hong Kong Perspective. HKIE Transactions, 8(1), 7-12.
Pearson, M. and Skues, D. (1999). Control of projects implemented through design and build contracts. Seminar Proceedings on Design and Build Procurement System, January 1999, Hong Kong, 49-60.

Rwelamila, P. D. and Hall, K.A. (1994). An inadequate traditional procurement system? Where do we go from here? East meets West, CIB-W92 Symposium, Hong Kong, 107-114.

Riggs, J. L., Goodman, M., Finley, R. and Miller, T. A. (1992). Decision support system for predicting project success. Project Management Journal, 22(3), 37-43.

Rizzo, J. (1998). Design/build alternative: a contracting method. Journal of Management in Engineering, ASCE, 14(6), 44-47.

Rowlinson, S. M. and Walker, A. (1995). The construction industry in Hong Kong, Longman.

Scott, P. S. and Showalter, W. E. (1986). The history of construction management. Construction Management: a state-of-the-art Update, October 27, 1986, Boston, Massachusetts, USA, 51-61.

Smith, A. and Wilkins, B. (1996). Team relationships and related critical factors in the successful procurement of health care facilities. Journal of Construction Procurement, 2(1), 30-40.

Songer, A. D. and Molenaar, K. R. (1996). Selecting designbuild: public and private sector owner attitudes. Journal of Management in Engineering, ASCE, 12(6), 47-53.

Tam, C. M. (1997). Design and build for a complicated re-development project in Hong Kong: The Happy Valley Racecourse Redevelopment. CIB W92 Symposium 1997, University de Montreal, May 1997, 743-750.

Walker, A. (1995). Hong Kong: The contractors' experience, Hong Kong University: Hong Kong.

Wilkins, B. (1999). Customer Orientation in the Delivery of Public Works - The Impact on Building Procurement in Hong Kong. Profitable Partnering in Construction Procurement, CIB W92 and CIB TG 23 Joint Symposium, E\&FN Spon, Longdon, 147-155.

Works Bureau (1999). Administrative procedures for use with The Government of The Hong Kong Special Administrative Region General Conditions of Contract for design and build contracts, HKSARG, 1999 edition. 


\section{INSTRUCTIONS AND GUIDELINES FOR AUTHORS TO THE AUSTRALIAN JOURNAL OF CONSTRUCTION ECONOMICS AND BUILDING}

SUBMISSION

Two issues (June and December) per annual volume of the journal are planned. Authors are requested to submit papers for publication at any time to:

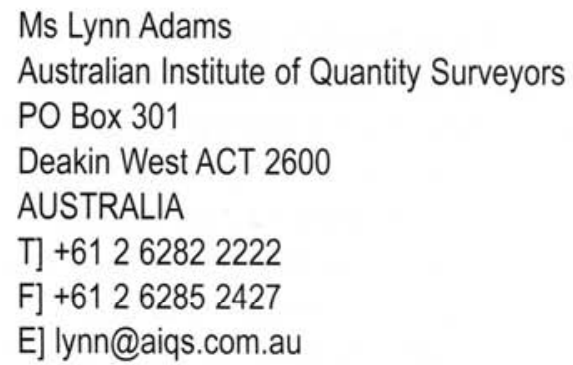

Papers will be referred to acknowledged experts for comment as to suitability, originality, interest and content. Only those receiving favourable recommendations from the referees will be accepted for publication. If an author is uncertain about whether a paper is suitable for publication, it is acceptable to submit a synopsis first.

\section{Submission of disks}

Disks must be supplied with the manuscript. Contributors should submit a 3.5 disk formatted on a PC or Macintosh computer in MS Word (version 5 and above) and/or Excel (version 4 and above) or email their papers to the above address.

\section{Effective communication}

The paper should be written and arranged in a style that is succinct and easily followed. An informative title, a concise abstract and a well-written introduction will help to achieve this. Simple language, short sentences and a good use of headings all help to communicate information more effectively. Discursive treatments of the subject matter are discouraged. Figures should be used to aid the clarity of the paper, not pad it out. Think about your reader.

\section{English language assistance}

As the language of the publication is English, it is strongly recommended that non-English speaking authors seek assistance from a competent English writer to ensure the spelling, grammar and style are correct. The Editor may be able to assist in identifying appropriate people to consult.

\section{Manuscript}

\section{(a) Presentation}

Depending on their nature, papers may be up to 5,000 words in length. Manuscripts should be typed 1.5 spacing, left hand justified, including references. A brief autobiographical note should be supplied including full name, position held and name of employing organisation. The manuscript should be arranged under headings and subheadings.

\section{(b) Title page}

The first page of the manuscript must contain the full title, the affiliation and address of the author(s), a running title of not more than 75 characters and spaces, the name and address of the author who will be responsible for correspondence and correcting the proofs, and up to five keywords for the purposes of indexing.

\section{(c) Keywords}

Authors should also provide 5 keywords or descriptors that clearly describe the subject matter of the article. These terms have two purposes: to help describe the subject content of an article to prospective readers; to index the article for retrieval from a database or bibliography. Such keywords might include: Country, geographical area, e.g. New Zealand, Micronesia; Organisation/ organisation related, e.g. Building Industry, Public Works; People, e.g. consultants, quantity surveyors, sub-contractors; Specific processes, technologies or applications, e.g. databases, TQM, advanced manufacturing technology; Broad functions or disciplines, e.g. information technology, cost management, innovation studies; Other processes and subject areas, e.g. industrial relations, economics, design, research

\section{(d) The abstract}

An abstract should be included. It must not exceed 200 words and must precis the paper giving a clear indication of the conclusions it contains.

\section{(e) Illustrations}

Illustrations must accompany the manuscript but should not be included in the text. Photographs, standard forms and charts should be referred to as 'Fig. 1', 'Fig. 2' etc. They 
should be numbered in the order in which they are referred to in the text. Indicate where in the text you wish the figure to appear. Send accurate and clear drawings to enable good reproduction.

Tables should be numbered consecutively and independently of any figures. Each table must have a number, a brief title, and headings down and across. Type tables on separate sheets of paper, and indicate in the text where you wish them to appear.

Photographs, preferably transparencies, should be labelled with the figure number and an indication of which is top. Where lettering is to appear on the photograph, two prints should be supplied, one of which should be left unlettered.

\section{(f) Measurements}

Metric units should be used; if other units are used then metric equivalents should be given in parentheses.

\section{(g) References}

The Harvard system is used. References in the text should be quoted in the following manner: Smith (1975 ) ... or ...

Brown and Green, (1976) ... or, if there are more than two authors ... Jones et al. (1980). References should be collected at the end of the paper in alphabetical order by the first author's surname. If references to the same author have the same year, they should be differentiated by using 1980a and $1980 \mathrm{~b}$ etc. The style should follow the examples below:

Smithers, N. (1966). Cost benefit analysis in town planning. Urban Studies, 33, 4-27.

Stone, P. A. (1980). Building Design Evaluation: Costs-InUse. E. \& F.N. Spon, London.

Burnes, S. (1981). Implementation of public policy. In Policy and Action (edited by S. Barrett and C. Fudge), 1-33. Chapman and Hall, London.

If no person is named as the author the name of the organisation should be used, for example:

Australian Institute of Quantity Surveyors. (1980). Report on Quantity Surveying Methods, Canberra.

To reference a website, include the author (be it an individual, organisation or institution), title of document, date the document was created, date it was viewed and the URL, for example:

International Council for Research and Innovation in Building and Construction 2000, W100-Environmental Assessment of Buildings, Results, International Conference Sustainable Building 2000, 22-25 October, Maastricht, The Netherlands viewed 14 July 2003 , $<$ http://www.cibworld.nl/pages/ib/0005/Pages/Around/W10 0.html>.

\section{(h) Notes}

A limited number of explanatory endnotes is permissible.

These should be numbered 1, 2, 3, consecutively in the text and denoted by superscripts. They should be typed on a separate sheet of paper at the end of the text. Endnotes should not be used for academic or project citations.

\section{Proofs}

Proofs will be sent to the corresponding author for correction. The difficulty and expense involved in making amendments at proof stage make it essential for authors to prepare their manuscript carefully: any alterations to the original text are strongly discouraged. Our aim is rapid publication: this will be helped if authors provide good copy following the above instructions, and return their proofs as quickly as possible. The editors reserve the right to amend style, grammar and typographical errors without reference to the authors.

\section{Copyright}

Submission of an article to the Australian Journal of Construction Economics and Building is taken to imply that it represents original, unpublished work, not under consideration for publication elsewhere. Authors submitting articles for publication warrant that the work is not an infringement of any existing copyright and will indemnify the publisher against any breach of such warranty.

On submitting a manuscript, authors will be asked to transfer the copyright for their article to the Publisher if and when the article is accepted for publication. The copyright covers the exclusive rights to reproduce and distribute the article, including reprints, photographic reproductions, microfilm or any reproduction of a similar nature, and translations.

Permission to publish illustrations must be obtained by the author before submission and any acknowledgments should be included in the figure captions.

\section{Refereeing procedure}

The decision whether or not to publish is the Editorial Board's. At least two members of the Editorial Board, and/or other acknowledged experts will be consulted. 
Scanner's note: This is a blank page 
Scanner's note: This is a blank page 
Scanner's note: This is a blank page 


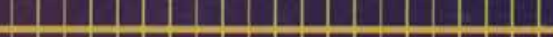
กด 